\title{
БАВНОТО ОТКРИВАЊЕ НА МАКЕДОНЦИТЕ
}

\section{Кратка содржина}

Постојаното тврдеюе, дури и во 21 век, дека Македонцчите се измислена нација од страна на Коминтерната и Титова Југославија, налагаат истражувағьа со цеел да се покаже дека формирането на македонската нација воопшто не било решение на една интернационална левичарска организација, туку дека тоа е еден природен процес, сличен како и кај другите нации во регионот. Блискоста на македонскиот со бугарскиот, а делумно и со српскиот јазик воопито не е аргумент за негиранье на постоенето на македонскиот како посебен јужнословенски јазик. Кон крајот на 19 и почетокот на 20 век, борбата која ја поведе Македонската револуциионерна организацција за создаване автономна македонска држава предизвика огромен интерес кај дипломатите, политичарите, новинарите и интелектуаличите во Европа, но и во САД. Како резултат на тој интерес излегоа многу студии и памфлети поврзани со Македонија и можното решаватье на македонското прашане. Навидум, тезите на науките од некои соседни земји одат во нивен прилог, но сепак внимателното истражуване покажува нешто сосема спротивно. Имено, многумина забележале дека македонското словенско население воопито не било ниту бугарско ниту српско, туку еден посебен јужнословенски народ присвојуван од соседите. Исто така, како на пример во САД, каде имало право на слободно деклариранье на националното чувство, дел од македонските емигранти се изјасниле така како што се чувствувале, односно како Македонци.

\section{Клучни зборови: НАРОД, ЈАЗИК, МАКЕДОНСКИ СЛОВЕНИ, МАКЕДОНЦИ}

Британецот Џон Фостер Фрејзер патувајќи низ Балканот на почетокот на 20 век ја посетил и османлиска Македонија. Во својата книга посветена на Балканот тој се осврнал и на етнолошката состојба во споменатата османдиска област. Фрејзер си го поставил прашањето: Кои се Македонците? Според него можеле да бидат најдени Бугари и Турци кои себе си се сметале за Македонци, можеле да бидат забележани и Срби и Грци кои се декларираде за Македонци, а можно е да се најдат и Романци кои се сметале за Македонци. За него не постоел ниту еден христијанин во Македонија кој не бил Бугарин, Србин, Грк, Турчин или Романец (Frazer: 1906, 5). Десно е да се заклучи дека за него не постоел посебен македонски народ, туку името Македонец било поврзано со регионот Македонија. Постојат и други примери кои говорат во насока на тоа што го напишал Фрејзер. Тука, поради ограничениот простор би ја спомнале и статијата објавена во 
британското списание „Quarterly Review“ каде може да прочитаме слично размислување како она на Фрејзер. Според непотпишаниот автор на статијата, македонска нација како посебна не постоела, туку терминот Македонец се користел за да ги означи сите жители на регионот Македонија (Quarterly Review:1903, 472). За авторот на статијата сосема била погрешна мислата на Гледстон за Македонија на Македонците, бидејќи последните не биле посебен народ. (Quarterly Review:1903, 480). Постојат бројни други примери кои не забележуваат или пак признаваат постоење на посебен македонски или на македонски словенски народ. Навидум работите се јасни за тогашните патописци, дингвисти, историчари, новинари или дипиомати. Сепак, внимателното истражување нѐ води кон еден друг поглед од кој може да извлечеме сосема пораздичен заклучок.

Чешкиот славист Нидерле бил застапник на тезата дека Македонците говорат бугарски дијалект и имаат бугарско народносно самосознание. Сепак, внимателното читање на некои од неговите дела откриваат нешто сосема друго од тоа што овој познат чешки славист пишувал во неговите трудови. Во својата книга „Македонското прашање“ Нидерле детално го објаснува проблемот кој ја оптоварувал и европската дипломатија, но и односите помеѓу балканските држави кои меѓусебно војувале за Македонија под изговор дека ги ослободувале своите сонародници во оваа област. Иако Нидерле бил застапник на тезата дека Македонците се Бугари, а нивниот јазик бил бугарски, во оваа негова книга сретнавме едно интересно размислување. Пишувајќи за националноста и јазикот на Македонците, Нидерле и покрај својот став дека истите биле Бугари, напишал „Со ова не сметам дека прашањето на народноста на македонските Словени е одговорено, посебно ако фрлиме поглед врз некои делови од Македонија...", (Нидерле, 2014:41) Оваа негова мисла ме поттикна да истражувам зошто, иако тој Македонците ги сметал за Бугари, напишал дека прашањето на македонската националност е неодговорено.

Истражувањата секогаш носат многу прашања, но и интересни наоди. Прашањето за јазикот на Македонците во текот на 19 и почетокот на 20 век се сметало дека било одговорено и истото било јасно. Најголем дел од тие што пишувале за Македонија и Македонците сметале дека словенското население во Македонија било бугарско, но имало и такви кои сме-

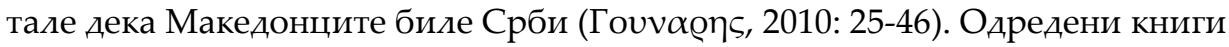
од 19 век ни даваат интересни податоци кои може да помогнат во давањето на одговорот зошто Македонците не биле забележани како посебен народ или пак зошто постоела раздика помеѓу нивното дефинирање како Бугари или Срби, а подоцна како посебен словенски народ.

На Балканот, во текот на првата половина на 19 век, активни станале протестантските мисионери кои преку преводите на Библијата на иокалните дијалекти и јазици настојувале да го остварат своето вдијание. Неколкувековното османдиско владеење со регионот предизвикало заборавање на минатото на народите од регионот, но и недостаток од христијански 
теолошки текстови на докалните јазици и дијалекти. Светото писмо било преведувано од англиски на некој од балканските јазици или дијалекти. За своите активности, протестантските мисионери редовно пишувале во списанието „Missionary Herald“. Во еден од броевите на ова протестантско списание најдовме текст кој се однесува на преводот на Новиот завет на балканските јазици. Така, во известувањето за преводот на Библијата е напоменато дека словенската верзија од времето на Кирил и Методиј била неразбирлива за обичниот човек. Така, свештеникот Неофит ја превел Библијата од словенски на македонски дијалект, а Петко Славејков од грчки на источнобугарски дијалект. (Missionary, 1867:381). Иако авторот иди авторите на овој текст сметале дека македонскиот и источнобугарскиот дијалект биле еден јазик, сепак преводот на два посебни дијалекти ја покажува раздиката меѓ нив. Инаку зошто би се преведувала Библијата на македонски дијалект доколку источнобугарскиот бил разбирлив во Македонија?

Спомнувањето на преводот од словенски на македонски дијалект на некој начин го отвора прашањето каде настанал тој словенски или поточно старословенски јазик? Одговорите биле јасни, но и интересни. Чешкиот славист и свештеник Јозеф Добровски, пишувајќи за настанувањето на старословенскиот јазик забележал дека старословенскиот јазик од времето на Кирил и Методиј бил српско-бугарско-македонски дијалект, јазик на Словените од Солун (Biblical, 1834:346). Оваа интересна констатација на Добровски нѐ води кон една друга теза за јазикот на словенското население во Македонија од средниот век, во 19 век и подоцна бидо означувано како старобугарски или бугарска варијанта на старословенскиот јазик. Ова секако е поврзано со нашата тема, но и со односот кон определувањето на припадноста на македонското население. Во 1916 година се појави една статија на Принс за еден старословенски текст, хрватска варијанта, напишан на глаголица кој се наоѓал во една приватна библиотека во Њујорк. Според Принс сосема погрешна била тезата старословенскиот јазик, настанат во Македонија, да се нарекува старобугарски (Prince, 1916:359). За него несловенските Бугари го прифатиле словенскиот идиом кој помалку се раздикувал од српскиот и рускиот во однос на црковнословенската форма на македонскиот. Може да закдучиме дека тој го раздикувал средновековниот старословенски јазик кој се говорел во Македонија и оној на словенизираните Бугари. Во таа насока би спомнале и една книга која се појавила во Ангдија во 18 век и се однесувала на словенските јазици. Според авторот на книгата во словенските јазици бил и западномакедонскиот (Brerewood, 1774:70) и сето ова нѐ води кон едно логично прашање дали имало односно дали странските научници, патописци, новинари или дипдомати ги забележувале Македонците како посебен народносен елемент без разлика дали ги нарекувале Македонци, Славомакедонци или Македонски Сдовени? Одговорот е позитивен. Треба сепак да се каже отворено дека биле во помал број во однос на оние кои Македонците ги поврзувале со соседните народи, посебно со Бугарите. 
Избувнувањето на Големата источна криза во 1875 година повторно го врати Балканот во центарот на вниманието на европските влади и јавност. Во европските земји со голем интерес се следеле настаните во регионот, а европските сиди покажаде голема активност со цел да дојде до смирување на состојбите, но и да ги остварат своите интереси. Последното особено било важно за Русија и за Австро-Унгарија. Во европскиот печат постојано било пишувано за балканските состојби, а исто така биле објавени и многу книги, статии и пропагандни брошури за регионот и за неговата иднина. Активност покажале и некои интелектуалци и дипломати од балканските земји. Тука мислиме на оние од независна Грција и автономна Србија. Па така, во влијателното британско списание „Macmillan's Magazine“ била објавена една статија која се однесувала на размислувањата за Источното прашање од балканска гдедна точка. Авторот на статијата се потпишал со псевдоним и според потписот бил Србин. Самата статија не би била интересна за нашиот труд доколку во неа не била спомната и Македонија. За авторот во Македонија живееле Срби и Бугари, но и еден друг народ кој тој го именувал како Македонци (A Servian, 1876-1877). Според него Македонците ги имадо 1000000 на број. Мошне интересен е неговиот став за јазикот на Македонците, како што тој ги нарекува, кој се наоѓал помеѓу српските и бугарските дијалекти (A Servian, 1876-1877:161). Ова негово размислување во иднина ќе го делат и други автори.

Појавата на Македонската револуционерна организација, во 1893 година, и нејзината борба за автономија на Македонија, придонела на почетокот на 20 век да се актуадизира македонското прашање. За Македонија и за состојбите со нејзиното население покажале интерес голем број на новинари, политичари, дипломати и научници. Секако во склоп на тој интерес била и етнолошката ситуација, таква каква што ја доживувале. Не би било научно коректно доколку не споменам дека многумина и тогаш Македонците ги поврзувале со Бугарите, но сепак сѐ повеќе било забележдиво дека македонската борба е автохтона, но и дека македонското население сепак не било бугарско. Настаните во Македонија ги заинтересираде и научниците од словенските земји или државите кои имале голема словенска популација, како на пример Австро-Унгарија. Во Виена во 1903 година се појавила една книга во која се објаснувале состојбите во Македонија. Автор на книгата Македонија и проблемите во Турицја бил извесен Герсин. Всушност зад овој псевдоним стоед Словенецот Нико Жупанич. Книгата, за жал не ја користевме, но во „Һубљанско звоно“ се појавила критика за истата. Во критиката се говори за словенските Македонци, Македонци и за нивната борба за слобода против османдиската власт. Од неа дознаваме дека авторот проценил дека мнозинството од населението во Македонија го сочинувале Македонските Словени кои броеле 2146336 (А.А., 1903: 314 - 315). Веќе следната година Нико Жупанич објавил една студија за Македонија, за нејзината историја, култура и народносниот состав. Тука ќе се задржиме на неговото размислување за Македонците и прашањето дали тие се 
посебен народ во однос на Бугарите и Србите, прашање кое сѐ повеќе ги преокупирало и научниците и политичарите и дипломатите. Пишувајќи за македонската историја, Жупанич забележал дека еден од најтажните моменти за македонските Словени било укинувањето на Охридската архиепископија во 1767 година и нејзиното припојување кон Цариградската патријаршија (Županić, 1904: 79). Ова намерно го потенцираме бидејќи за раздика од годем број други автори, тој Охридската архиепископија на ја поврзува со Бугарија. Исто така, за него Самоиловото Царство е шопско македонска држава (Županić, 1904: 88). Жупанич е мошне внимателен кога говори околу прашањето за постоењето на Македонците, но сепак може да закдучиме дека тој користејќи го името шопски Македонци, а споменува и таков јазик, ги одвојува нив од Бугарите и Србите, иако смета дека недостатокот на развиена национална свест може да доведе до нивно претопување (Županić, 1904: 86-88). Сличен интерес за македонските состојби бил покажан и во Чешка. Во едно тамошно вдијателно списание познатиот правник Бохумия Бакса ја објавил статијата „Македонското прашање“. Во неа тој се осврнал и на етнолошкиот состав на населението во Македонија. Според него, мнозинството од населението го сочинувале македонските Словени, кои биле присвојувани и од Бугарите и од Србите (Ваха, 1903: 714). Бакса е мошне внимателен во именувањето на Македонците, иако може да забележиме дека е воздржан во тврдењето дека тие се посебен народ, сепак тој нив ги именува како македонски Сдовени. Слично на Бакса размислувал и Карасек кој објавил една помала студија за јазикот на како што ги нарекува македонските Словени. Карасек сметал дека народноста на македонските Сдовени може да се одреди после целосното проучување на нивниот јазик, а српските и бугарските тврдења ги сметал за политички и дел од нивната пропаганда (Karasek, 1903: 116-117). Интересно е да забележиме дека тој сметал оти најголемиот дел од масата на населението се чувствувала како македонска, но интелектуалците биле поделени на Срби и Бугари (Karasek, 1903: 117). Оваа негова забелешка е најверојатно точна и подоцна ќе има вдијание врз решавањето на македонското прашање.

Македонците се јужносдовенски народ кој има сопствен јазик, за жал и денес оспоруван, иако славистиката, со исклучок на бугарската, одамна го има признато како посебен. Затоа во овој дел од нашиот труд ќе дадеме еден пример кој говори како некои словенски научници гледале на македонската посебност. Професорот П.Е. Казански од Одеса во својот извештај за општословенскиот Собор во бугарската престолнина дал некои размислувања за делувањето во иднина. Меѓу другото тој забележал дека на Соборот не биле претставени сите политички партии, но и понеразвиените „словенски племиња (Македонци, Лужичани)“ (Славянскиій, 1910: 30). Ова само ни покажува дека во некои руски кругови веќе било јасно постоењето на посебен словенски народ - македонскиот.

Завршувањето на Балканските војни, протерувањето на Османлиите од регионот и поделбата на Македонија помеѓ балканските држави не 
значело и крај на прашањето за припадноста на македонското население. Јерг во својата студија посветена на новите граници во регионот и прашањето на судбината на населението се осврнал и на Македонија. Според неговото размислување Македонците би требало да бидат сметани како Словени кои се наоѓаат помеѓу Србите и Бугарите (Joerg, 1913: 829). Ваквите размислувања не биле нови, ниту пак ќе престанат да бидат издожувани во следниот период.

Воспоставувањето на Македонскиот фронт во Првата светска војна каде војските на Антантата и на Централните сили воделе жестоки битки предизвикало големи страдања на локалното население. Меѓутоа офицери на завојуваните страни, новинари, обични војници започнале да пишуваат книги и статии за самите воени дејствија во кои се осврнале и на локалното население. Италијанецот Яуиџи Вилари бил офицер за врски во британската команда на Македонскиот фронт. Една деценија по завршувањето на Првата светска војна била објавена една негова статија за македонското прашање. Интересно е да се забележи дека Вилари сметал оти Македонците биле повеќе наклонети кон Бугарија отколку кон Србија, но сепак ги рангирад како посебен народ. Според него трите народи - Србите, Бугарите и Македонците зборувале многу слични словенски јазици. Историјата ги раздвоила Србите и Бугарите, а Македонците, народносно и јазично биле помеѓу нив (Villari, 1928:152). Британецот Даглас Волш бил на Македонскиот фронт и по завршувањето на воените операции објавил една книга во која ги изнел своите впечатоци. Тој во својата книга посветена на настаните на Македонскиот фронт се осврнал и на локадното население и секако на делувањето на британските војници. Интересно за темата која ја обработуваме е неговата забелешка за јазикот, поточно за еден од јазиците кои се говореле во Македонија. Пишувајќи за словенскиоте муслимани тој забележал дека тие говорат македонски или како што напишал таcedonski (Walshe, 1920:188). Волш опишувајќи го секојдневието на британскиот војник на фронтот се осврнал и на јазиците кои војникот ги слушал и тука го спомнува јазикот како macedonski (Walshe, 1920: 199).

Мислењата на Вилари и Волш околу населението во Македонија и јазикот, кој тоа го зборувало, не биле единствени во времето на Првата светска војна. Иако воените дејства биле главниот интерес на јавноста во тој период, научниците се занимавале со своите теми и истражувања. Прашањето за Македонците и нивниот јазик односно дали тој постоел како самостоен или пак бил дијалект на некој друг словенски јазик, пред сѐ на бугарскиот, продолжувало да биде тема во некои статии. Деон Доминиан во својот труд за јазичните области во Европа се осврнал и на состојбите во Македонија која веќе била дел од четири балкански држави. Иако повеќе сметал дека Македонците и нивниот јазик се бугарски, внимателното читање на неговата статија покажува една неодреденост по тоа прашање. Доминиан пишува дека Македонците како народ се преоден елемент помеѓу Србите и Бугарите. Истото го констатира и за македонскиот јазик (Domini- 
an, 1915: 436). Една година подоцна се појави студијата на Бак за јазикот и националноста. За раздика од Доминиан, Бак прави споредба на проблемот со јазикот на Македонците со некои други примери од словенскиот свет. Според него постојат прашања дали словачкиот јазик е посебен или дијалект на чешкиот, дали украинскиот е посебен или дијалект на рускиот и тоа што е за нас интересно дали словенскиот говор во Македонија е бугарски, српски или македонско словенски (Buck, 1916:61). За него дингвистите се поделени околу ова прашање. Овие два примери ни покажуваат колку било тешко да се признае фактот дека македонскиот јазик, иако сѐ уште не бил кодифициран, сепак постоел како што постоеле и постојат говорни јазици кои не биле и не се кодифицирани.

Интересно е да се забележи дека за време на Првата светска војна се водела една подолга и жолчна дискусија помеѓу Херман Вендел, германски пратеник од Социјал-демократската партија и Димитар Ризов, бугарски дипломат од македонско потекло. За Ризов, кој по потекло бил од Битола, припадноста на Македонците била јасна - тие биле Бугари. За нас поинтересно е мислењето на Вендел, кој од страна на Ризов бил обвинуван дека имал просрпски ставови кога била во прашање Македонија и тамошното словенско население. Сепак внимателното читање на текстовите на Вендел нѐ води до заклучок дека тој Македонците не ги сметал ниту за Бугари, ниту пак за Срби, туку за посебен словенски народ кој сѐ уште, поради историските околности, немал изградено цврста национална свест. (Вендел, Ризов, Томиќ, 2014: 5-8, 17-23). Интересно е да се забележи дека Вендел, во дискусијата со Ризов, се повикувал и на автори кои сметале дека Македонците не биле ниту Бугари, ниту пак Срби. За нас е интересно мислењето на Теобалд Фишер, кој како што ни прикажува Вендел, сметал дека „мнозинството од македонското население не е ниту српско, ниту бугарско, туку самото е формирано од јужните Словени во Македонија без јасно национално чувство“ (Вендел, Ризов, Томиќ, 2014: 7). Треба да се потенцира дека Вендел и Ризов во текот на Првата светска војна биле претставници на две сојузнички земји во рамките на Централните сили - Германија и Бугарија. Самиот Вендел по завршувањето на војната го посетил делот од Македонија кој бил во рамките на новоформираното Кралство на Србите, Хрватите и Словенците и своите впечатоци ги изнел во една негова книга. За време на посетата на Македонија, Вендел во Ресен на неговото прашање до група деца што се по националност го добия одговорот - Македонци, а во соседна Битола се сретнал со еден тамошен интелектуалец кој му говорел за посебна македонска народност и желбата за создавање на македонска автономна област со седиште во Скопје (Wendel, 1922: 92).

За време на Првата светска војна, во војските на Централните сили кои се бореле на Македонскиот фронт, а претходно и на другите балкански боишта, имало и научници од разни области кои правеле одредени студии, а потоа ги публикувале или пак одржувале предавања на темите поврзани со Балканот. Едно такво предавање било одржано во Виена во 
март 1917 година од страна на професорот Еуген Оберхумер со наслов „Балканските народи“. За нас е интересен делот кој се однесува на населението на полуостровот. Овој австроунгарски географ забележал дека контроверзноста околу припадноста на словенските Македонци била особено насилна, иако тие сѐ повеќе себе си се нарекувале Македонци (Oberhmmer, 1917: 296-298). Оберхумер сметал дека било потребно понатамошно разјаснување за јазикот на ова население.

По завршувањето на Првата светска војна едно од прашањата кое било актуелно во Европа се однесувало на националните малцинства во новосоздадените држави како резултат на војната и Париската мировна конференција. Се појавиле интересни книги и статии кои, меѓу другото, се однесуваде на Македонците, поточно дади тие се посебен народ. Тука ќе дадеме некои примери кои се во насока на македонската народносна посебност. Создавањето на новата југословенска држава со името Кралство на Србите, Хрватите и Словенците предизвикала и научен интерес за етнолошките состојби во неа. Македонците не биле признати како посебен народ во неа, туку биле сметани како Јужни Срби. Сепак, во едно словенечко списание може да забележиме интересно размислување. Антон Иобода, пишувајќи за проблемот на македонското население и присвојување од страна на Србите и Бугарите, забележал дека помеѓу Македонците се јавила струја која сметала дека македонските Словени се посебен јужнословенски народ (Loboda, 1918:65). Зборовите на Аобода не биле единствени и осамени. Британскиот историчар Темперли во својата книга за историјата на Србија, се осврнал и на прашањето на постоењето на Македонците. И тој како и другите во овој период пишувал за раздичните погледи за припадноста на македонското население, но и за слабо развиената национална свест кај македонското население. Иако навидум тој пишува за Бугари, сепак Темперли забележал дека постои македонски народ и македонски јазик, кој е посебен во однос на бугарскиот и српскиот иако е доста сличен и адаптибилен (Temperley, 1919:312). Слично како Добода и Темперли, пишува и Боуман. Во неговата книга за политичката географија и новиот свет по Првата светска војна тој посветил внимание и на состојбите на Балканот, а Македонија и Македонците не можеле да бидат изоставени. Боуман објавил една карта на која јасно ги означил Македонците како посебен народ во регионот кој населувал делови од Кралството СХС и Грциja. (Bowman, 1922:234). За него Македонците се посебен народ раздичен од Бугарите.

Постоењето на Македонците како посебен народ кој има сопствен јазик не бил нагласуван само од странските интелектуалци, научници, новинари, туку во некои западни публикации бил промовиран и од самите Македонци. Во истражувањата наидовме на една статија објавена во француско списание од извесен Гоце, име кое најверојатно е псевдоним на авторот. Во статијата со наслов „Македонската идеја. Унијата на балканските народи“, авторот ја објаснува состојбата во Македонија и македонската 
борба за слобода против османдиското владеење. Иако се залага за слобода на сите народи во Македонија и за создавање балканска федерација, авторот забележува дека Македонците говорат словенски јазик и живееле заедно со Грците, Романците, Албанците и Евреите (Gotse, 1928:9). Тој никаде не спомнува дека македонскиот јазик е бугарски иди пак српски, ниту пак пишува дека Македонците се Бугари или Срби.

Тешката социјална, економска и пред сѐ политичка состојба во османдиска Македонија предизвикала емигрирање на тамошното население, пред сѐ христијанското, во други делови од светот. Македонците не биле исклучок од овој процес. За првпат тие можеде да видат еден нов просперитет, свет каде животот не бил во толку голема опасност како што тоа се случувало во Османдиската Империја. Македонските емигранти имале можност, заради американската демократија, слободно да го изразат својот идентитет и да се искажат како Македонци кои говорат македонски јазик, кој тогаш не бил кодифициран и не бил признат ниту во Османдиската Империја, ниту пак од страна на соседите и дингвистиката. Сепак и тој процес не бил едноставен и лесен. Примерот со означување на македонскиот јазик на почетокот на 20 век во САД е добар показател. Вдијанието на дингвистичката расправа за припадноста на македонскиот јазик, може да ја забележиме и во американските официјални документи. Треба да се каже дека првично и во американските службени книги забележуваме една конфузност околу прашањето кои се Македонците односно дали се посебен народ со свој јазик или пак се дел од бугарскиот народ. Во 1911 година била издадена една едиција во повеќе томови за потребите на американскиот имигрантски систем и влада. И тука ја сретнуваме таа конфузност околу Македонците. Имено, во еден од томовите кој се однесува на потекдото и јазикот на имигрантите постои еден мошне интересен дел кој се однесува на Македонците. Во делот под наслов Македонци кратко е наведено види Бугари (Dillingham 1, 1911:92). На прв поглед работите се јасни и прецизни, но не е баш така. Имено, во дедот кој се однесува на Бугарите, кога е во прашање јазикот ја забележуваме целата нејаснотија околу Македонците. Во инструкциите до оние кои ги запишуваде имигрантите, нивното потекдо и мајчиниот јазик бидо наведено дека е потребно да се објасни прашањето кое го сметале за најважно околу бугарските дијалекти односно т.н. македонски јазик. Според напишаното постоеле луѓе кои тврделе дека постои македонски народ и јазик, но тоа било сметано како некаков докален патриотизам, бидејќи во тие моменти на дингвистите од балканскиот регион такво нешто не им било познато (Dillingham 1, 1911: 27). Како што напишав на прв погдед сѐ било јасно, но самото објаснување дава простор за раздични интерпретации. Во истата едиција сретнуваме нешто што е најдобар демант на напишаното и е потврда на веќе сѐ појасната македонска народносна свест раздична од регионалната која била поврзана со Бугарите и Грците, па и со Србите. Имено, иако се повторува истата теза за македонскиот јазик, составувачите на овие извеш- 
таи напишале. „Повремено имигрант од Турција инсистира дека тој е Македонец, а не Турчин, Бугарин, Грк или Албанец“" (Dillingham 2, 1911: 282). Во таа насока на повеќе места од овој том од истата едиција именката Македонец и придавката македонски стои без никакви додатоци како израз на посебен идентитет (Dillingham 2, 1911: 356-530). Две децении подоцна прашањето околу јазикот и народноста на Македонците, во овие американски статистички книги издадени околу прашањето на имигрантите, е многу појасна. Па така во инструкциите до оние кои требало да ги пополнуваат пописните графи, како еден од мајчините јазици е наведен македонскиот (Instructions, 1930:30). Оваа промена била резултат, претпоставуваме, и на двоумењата кои постоеле на почетокот кај американските служби, но и на инсистирањето на македонските имигранти нивниот јазик да биде заведен како македонски. Пример за ова наше размислување е еден напис во американски дневен весник. Bo Harrisburg Telegraph се појавил напис во кој покрај словенски и ангдиски, како јазик се споменува и македонскиот на кој ќе се испечати еден циркулар за потребите на градот (Harrisburg telegraph, 1914:3). Кога е во прашање Северна Америка би сакале да забележиме дека македонска емиграција на почетокот на 20 век имало и во Канада, тогаш британски доминион. Засега не располагаме со официјални канадски податоци како што е случајот со американските, но постои една интересна книга за канадските емигранти. Во книгата има доста интересни податоци за Македонците, односно за нивната посебност во однос на другите народи од Балканот. Тука, заради просторот, ќе споменеме една класификација на словенските народи. Авторот на книгата, според научните сознанија, ги дели словенските народи на Источни, Западни и Јужни Словени. За нас е интересна поделбата на последната, јужнословенската група на народи. Па така може да ја видиме следнава класификација - Јужните Словени се поделени на Бугари, Македонци, Срби, Црногорци, Босанци и Херцеговци и Хрвати (Cameron, 1913: 34). И во другите делови од книгата Камерон јасно ги разграничува Македонците од другите народи. Едноставно може да забележиме дека Македонците во новиот свет можеле да се искажат и да се изборат за тоа што се, без да бидат издожени на притисокот од пропагандите на соседните држави кои целеле кон Македонија, а подоцна и на нивните вдади по поделбата на регионот во 1913 година.

На крајот се поставува прашањето зошто толку доцна, со толку недоумица и толку тешко доаѓ до препознавање и признавање на еден народ на Балканот, а тоа е македонскиот? Одговорот навидум е лесен, но во суштина е дедикатен и обемен. Првичното слабо познавање на состојбите на Балканот и во Македонија и лесното усвојување, прво на бугарското име, а подоцна и на српското од страна на странските научници, дипломати, патописци, новинари имале свое вдијание на погледот на етнодошките состојби во Македонија и прашањето за постоењето на Македонците како посебен народ. Едно од најинтересните објаснувања за проблемот на 
Македонците го најдовме во една книга објавена за време на Втората светска војна, значи пред создавањето на македонската држава. Според Ковач, автор на книгата, мнозинството од населението говори македонски јазик кој Србите го нарекуваат јужносрпски, Бугарите пак го сметаат за бугарски, додека Грците ова население го нарекуваат славофонско. За него најважен е фактот што самите Македонци никој не ги прашувал за нивното мислење (Kovacs, 1943:56).

\section{Питература:}

A.A, 1903, “K. Gersin, Macedonien und das Türkische problem”, Ljubljanski zvon, 314-315.

A SERVIAN, 1876-1877, "The Eastern Question from the point of view of the Eastern Christian", Macmillan's Magazine, 35, 158-176.

BAXA Bohumil, 1903, "Macedonska otazka", Česka revue, 6, 708-715.

BoWman Isaiah, 1922, The New World. Problems in political Geography, New York: World Book Company.

BREREWOOD Edward, 1774, Enquiries touching the diversity of languages and religions through the chief parts of the world, London: S.M.J.M and H.H.

BUCK, Darling Carol, 1916, "Language and the sentiment of Nationality", The American political Science Review, v. 10/1, 44-69.

CAMERON, R.J., 1913, Foreigners or Canadians?, Toronto: The Standard Publishing Co.

DiLlingHAM William, 1, 1911, Reports of the immigrants Commission, Dictionary of Races or Peoples, Washington: Government printing Office.

DiLlingHAM William, 2, 1911, Reports of the immigrants Commission, Abstracts of Reports of the Immigration Commission, Washington: Government printing Office

DOMINIAN, Leon, 1915, "Linguistic areas in Europe: Their boundaries and Political significance", Bulletin of the American Geographical Society, v.47/6, 401439.

FRAZER FOSTER, John, 1906, Pictures from the Balkans, London: Cassell and Company, ltd.

GoTSE, 1928, “L'idee macedonienne. L'Union des peoples balkaniques”, Le cri des peuples, $1 / 6$, Paris, 9.

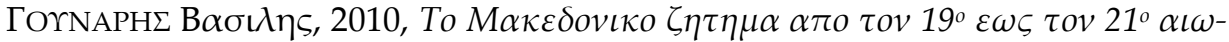

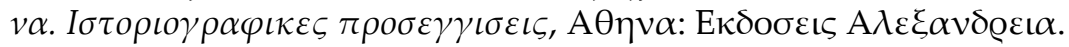

"Historical view of the Slavic language in its various dialects with the special reference to the theological literature", 1834, Biblical repository, vol. XIV, New York, 328-412. 
Instructions to enUmerators. Populations and Agriculture Fifteenth Census, 1930, Washington: Government printing Office.

JoERG, W.L.G., 1913, “The New Boundaries of the Balkan states and their significance", Bulletin of the American Geographical Society, v. 45/11, 819-830.

KARASEK Josef, 1903, “Několik slov o makedonskýh Slovanech", Slovanský Přehled, $r$. V, 113-119.

KovaCs Frederick, 1943, The Untamed Balkans, New York: Modern Ages Books.

LOBODA Anton, 1918, "Misli o slovanskih narodnostnih problemih", Ljubljanski zvon, XXXVIII, 64-73.

НИДЕРлЕ, Аибор, 2014, Македонското прашане, Скопје: АД Вербум.

OBERHUMMER, Eugen, 1917, Die Balkanvölke, Wien: Vortag.

PRINCE Dyneley J., 1916, "A Rare Old Slavonic Religious Manual”, Proceedings of the American Philosophical Society, v. 55/6, 357-362.

СЛАВЯНСКИІЙ СъЕЗДъ ВЪ СОФІИ, 1910, Отчетъ представитела Императорскаго Новороссійскаго университета ординарнога профессора П.Е. Казанскаго, Одеса.

TEMPERLEY Harold, 1919, History of Serbia, London: G. Bell and Sons.

"The Macedonian maze", 1903, Quarterly review, N. 394, April, 459-483.

"Translators of the Bible in Constantinople", 1867, Missionary Herald, v. LXIII, n. XII, 379-392.

ВеНДЕЛ Херман, Ризов Димитар, Светозар Томиќ, 2014, За Македонија и Македонцичте, Скопје: Pro Macedonia.

VILLARI Luigi, 1928, “The Macedonian problem", Royal UnitedService Instution Journal, 73, 151-157.

WALSHE, Douglas, 1920, With the Serbs in Macedonia, London: John Lane Bodley Head.

WeNDEL, Herman, 1922, Von Marburg bis Monastrir, Frankfurt M: Frankfurter Societats-Druckerei.

ŽUPANIČ Niko, 1904, “Macedonija (etnografska skica)”, Zbornik naučnih i poučnih spisov, z. VI, 71-101.

\section{Весници:}

Harrisburg telegraph, May 5, 1914. 